\title{
System Dynamic Model for Lake's Water Flow: A Case Of Situ Binong, Cikarang, West Java, Indonesia
}

\author{
Muchammad Chusnan Aprianto
}

Program Studi Teknik Mesin, Sekolah Tinggi Teknologi DR. KHEZ Muttaqien

Jl Letjend Basuki Rahmat No. 37, Sindangkasih, Purwakarta.

Email:chusnan82@gmail.com

\begin{abstract}
Abstrak
Penelitian ini bertujuan untuk mengembangkan model sistem dinamik yang menggambarkan hubungan sub-sistem air, sosio-ekonomi, dan sumber daya air (ukuran danau) di Situ Binong. Selain itu, penelitian ini juga bertujuan untuk membuat prediksi kondisi sumber daya air Situ Binong selama 5 tahun ke depan. Model disusun menggunakan pendekatan sistem dinamik. Model aliran air Situ Binong merupakan sumber daya air yang tersedia yang terdiri dari 3 sub-sistem yaitu sub-sistem aliran air alami, sosio-ekonomi, dan sumber daya air Situ Binong. Hasil penelitian menunjukkan bahwa kebutuhan sumber air Situ Binong setiap tahun meningkat sehingga volume Situ Binong menurun. Selain itu, volume sumber daya air Situ Binong dipengaruhi oleh pasokan dan permintaan. Pasokan berasal dari limbah domestik dan aliran air alami seperti pengendapan, infiltrasi dan aliran permukaan. Sedangkan permintaan berasal dari asupan WTP, irigasi, dan evaporasi.
\end{abstract}

Kata kunci: Sistem dinamik, aliran air, neraca air, limbah domestik, ekowisata.

\author{
System Dynamic Model for Lake's Water Flow: \\ A Case Of Situ Binong, Cikarang, West Java, Indonesia
}

\begin{abstract}
This study aims to develop a dynamic system model that describes the relationship of water, socio-economic, and water resources (lake size) sub-systems in Situ Binong. In addition, this study also aims to make predictions of water resources conditions (lake size) Situ Binong for the next 5 years. The model is prepared using a dynamic system approach. The Situ Binong water flow model is available water resources consisting of 3 sub-systems namely natural water flow sub-systems, socio-economic, and water resources Situ Binong. The result of the research shows that the requirement of Situ Binong water resources every year is increasing so that the volume of Situ Binong is decreasing. In addition, the volume of water resources Situ Binong influenced by supply and demand. Supply comes from domestic waste and natural water flow such as precipitation, infiltration and surface flow. While demand comes from WTP intake, irrigation, and evaporation.
\end{abstract}

Keywords: LPS antigen, ELISA, PBA, Salmonella Typhi 


\section{INTRODUCTION}

Water resources has become major role in people daily lives as well as in irrigation, agriculture, electrical power plan, and clean water supply. However, some water resources such as lakes and rivers became influenced with social activities such as industrialization and domestic waste and it has affect to the water quality. Therefore, Kotir et al. (2016) argue that water resources management should consider multi-discipline approach including dynamics issues, feedback processes, social-economic, population, policy, and biophysical processes. These processes could be simulate through system dynamics model which consider interaction between social-economic sub-system, population sub-system, and biophysical subsystem.

System dynamics is a method for problem analysis where time is the main factor and include a study of how a system will be maintained (Ford 1999). System dynamics used to analyze a system and its interaction between each sub-system with macro level, less detail, and strategic level as well as dynamic population, ecosystem, waste management, market places, man power and management, research and development in management, transportation management, and urban air pollution (Ercan, Onat, and Tatari 2016; X. Liu et al. 2015; Shahgholian and Hajihosseini 2009; Vafa-Arani et al. 2014). Recently, researchers are use system dynamics approach for water resources analysis such as river basin and lake management.

The interaction between water resources, population, and agricultural system can be simulated using system dynamics such as in the Volta River Basin in West Africa (Kotir et al. 2016). Another three sub-systems interaction were studied for the Dianchi Lake in Yunnan Province, China. The study shows three sub-systems loops (i.e. pollution, resource consumption, and pollution control) and their interactions with construct stock and flow diagram within system dynamics simulation model (H. Liu et al. 2015). While Kong et al. (2017) has simulate the interaction between the saline lake mineral resources, economic development, and ecological sub system. The system dynamics model is not only applied for social and economic interaction but also can be used for basic science such as relationship between the normalized difference vegetation index (NDVI), total nitrogen, and total phosphorus (Zhu et al. 2015). Even though their studies are limited for three sub-systems, the simulation is used as a tool to provide better understanding of river basin and lake to the policy-makers and support of decision-making for sustainable water resources management. However, Sun et al. (2017) has studied water resources management with five major subsystems i.e. population, economy, water demand and supply, land resources, and water pollution and management with provide a feedback loop and stock-flow of the systems in system dynamics simulation and estimate the future conditions and gaps between each system from 2005 to 2020 .

In Cikarang, Situ Binong Lake is one of many water resources that built in 1917 with 17 ha of area, $28^{\circ} \mathrm{C}-32^{\circ} \mathrm{C}$ of ambient temperature, and $86.37 \mathrm{~mm}$ per year of annual 
precipitations. As water resources, Situ Binong has a function for agriculture, irrigation, place of domestic waste, and village's ecotourism. Recently, Situ Binong has been used for source of water treatment plan managed by Ekamitra Foundation and it become the main source of water resources for local community around Situ Binong. Therefore, water resources in Situ Binong should be well sustained through holistic approach. However, its decision making of water resources management often not based on holistic view between socio-economic and biophysical processes. To overcome those problems, this study aims to: (1) present an integrated system dynamics simulation model based on social-economic and biophysical processes in Situ Binong; and (2) predict water resources condition based on policy scenarios for the next five years.

\section{METHODS}

\section{Study Site of Situ Binong Lake}

Situ Binong Lake (6 $200^{\prime} 34^{\prime \prime}-6^{\circ} 20^{\prime} 50^{\prime \prime} \mathrm{S}$ and $107^{\circ} 11^{\prime} 67^{\prime \prime}-107^{\circ} 10^{\prime} 50^{\prime \prime} \mathrm{E}$ ) is located in Hegarmukti Village, District of Bekasi, West Java, Indonesia. Situ Binong is an artificial lake that was built in 1917 with approximately 36 ha of area and elevation at $37 \mathrm{~m}$ above sea level (m a.s.1). During the time, the area of Situ Binong has been decrease to 24 ha in 1978 and 17 ha in 2009 until today. Situ Binong has $28^{\circ} \mathrm{C}-32^{\circ} \mathrm{C}$ of ambient temperature, 510,000 $\mathrm{m}^{3}$ volume capacity, and $86.37 \mathrm{~mm}$ per year of annual precipitations. Situ Binong is surrounded by Hegarmukti Settlement from north and west site with 16.667 total population, while the east site is Cikarang Pusat Highway as shown in Fig. 1.

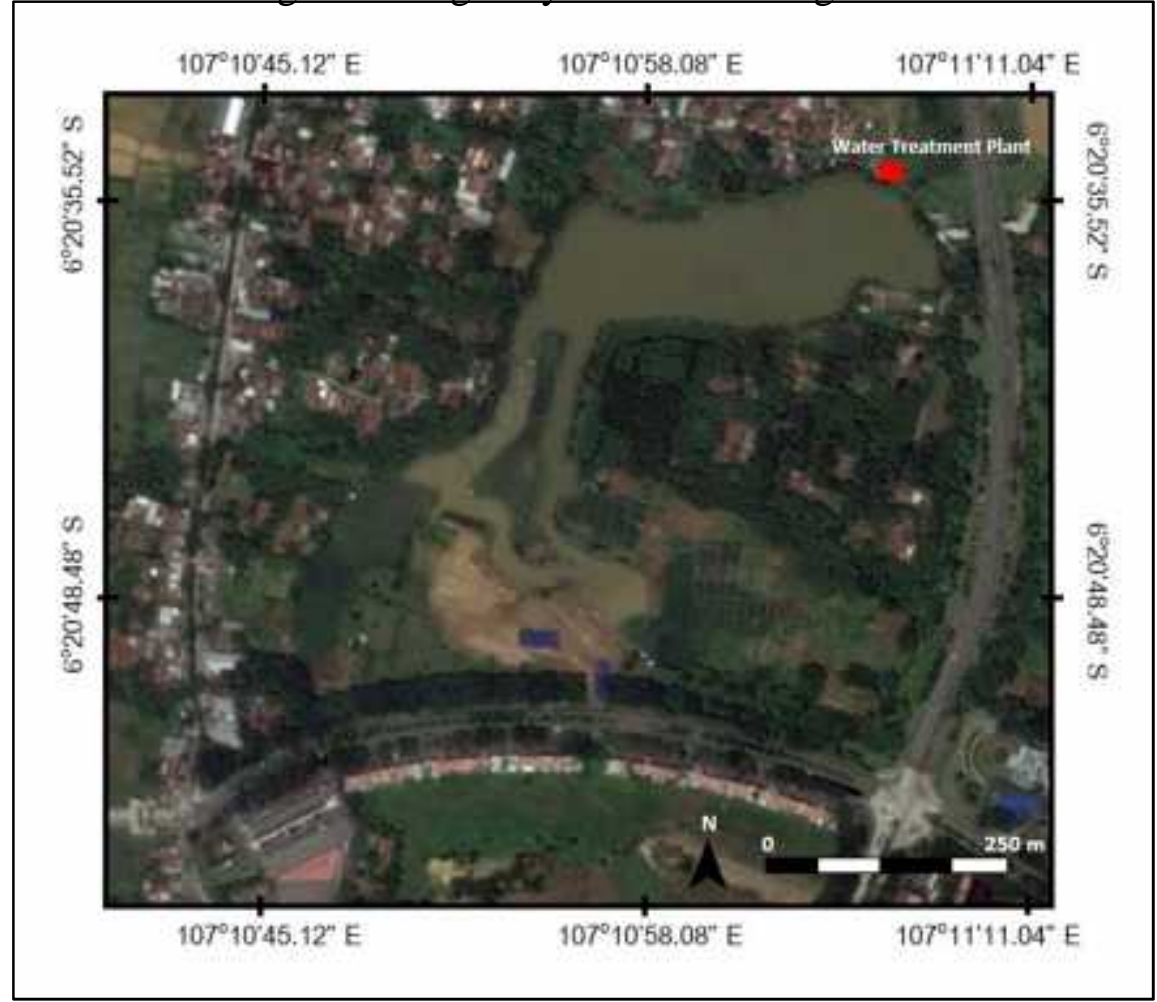

Fig. 1. Site of Situ Binong Lake with water treatment plant location. 
All input of Situ Binong are from surface run-off, precipitations, ecotourism activities, and domestic waste run-off. While all the output are evaporation, input of water treatment plant, and agriculture such as irrigation for paddy fields, hydroponic, and garden. Agriculture and water treatment plant are the major use of water resources in Situ Binong.

\section{Causal Loop Diagram}

System dynamics is used to analyze and predict a complex system based on empirical data and assumption and test the model with limited data. Causal loop diagram (CLD) is used to describe relationships among variables using closed chain of cause and effect (Kotir et al. 2016). Fig. 2 shows the relationships of variables from population subsystem, water treatment plant sub-system, agricultural sub-system, and ecotourism subsystem. CLD develop by FDG's (gathered people), qualitative data, data from Yayasan Ekamitra, and deep interview.

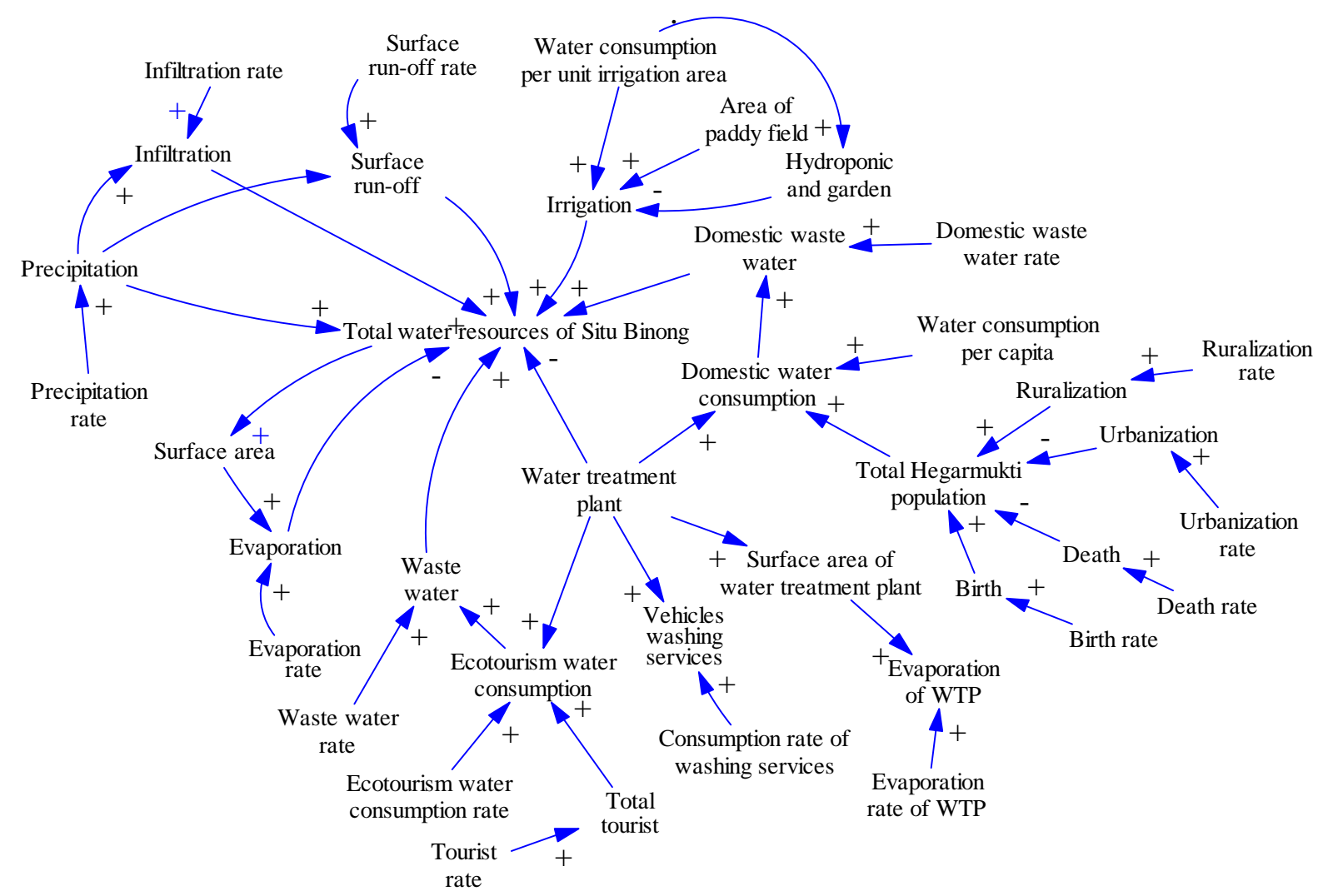

Fig. 2. Causal Loop Diagram for Water Resources in Situ Binong.

\section{RESULTS AND DISCUSSION}

\section{Variables of Water Resources in Situ Binong}

The dynamic system model in Situ Binong consists of four components: 1) Stock (state variable, level, or reservior); 2) Flow (average / rate, control variable, or process, constants); 3) Conventer (auxilliary or translation variables); and 4) Connector (or arrow information). This type of variable is shown in Figure 2. Stock variable is a variable with numerical integration equation that is variable value influenced by time. This type of variable 
is the population in Hegarmukti. Variable flow is a control variable or rate of change that affects other variables. For example, in variable model of waste water rate and water consumption per capita is a constant so that including type of variable flow. The conventional variable is a variable that is not influenced by time but is only influenced by other independent variables. For example, water treatment plan variables are influenced by costumers water demand variables, ecotourism water consumption, evaporation of WTP, and vehicles washing services. Variable stock and flow used in this research is shown in Table 1.

Table 1. Stock dan Flow Variable in System Dynamic Modelling of Situ Binong.

\begin{tabular}{|c|c|c|c|}
\hline $\begin{array}{l}\text { Type of } \\
\text { Variabel }\end{array}$ & Variabel & Initial Value & Unit \\
\hline \multirow[t]{5}{*}{ Stock } & Ecotourism water consumption & 81.7 & $\mathrm{~m}^{3}$ \\
\hline & Evaporation & 222888 & $\mathrm{~m}^{3}$ \\
\hline & Total Hegarmukti population & 13127 & people \\
\hline & Total water resources of Situ Binong & 510000 & $\mathrm{~m}^{3}$ \\
\hline & Water treatment plant & 35,478 & $\mathrm{~m}^{3}$ \\
\hline \multirow{16}{*}{$\begin{array}{l}\text { Konstanta/ } \\
\text { flow }\end{array}$} & Birth rate & 383 & people/year \\
\hline & Consumption rate of washing services & 0.1 & $\%$ \\
\hline & Costumer rate & 5 & costumer/year \\
\hline & Death rate & 7 & people/year \\
\hline & Ecotourism water consumption rate & 0.5 & $\%$ \\
\hline & Evaporation rate & 2.4 & $\mathrm{~m} / \mathrm{m}^{2} /$ Year \\
\hline & Evaporation rate of WTP & 0.00096 & $\mathrm{~m} / \mathrm{m}^{2} /$ year \\
\hline & Feedback water rate & 0.7 & $\%$ \\
\hline & Precipitation rate & 1.5 & $\mathrm{~m} /$ year \\
\hline & Precipitation rate area & 1.24 & $\mathrm{~m}^{2} /$ year \\
\hline & Ruralization rate per year & 10 & people/year \\
\hline & Tourist rate & 312 & people/year \\
\hline & Urbanization rate per year & 1.48 & people/year \\
\hline & Waste water rate from ecotourism & 0.1 & $\%$ \\
\hline & Wasted water rate from domestic & 22.3 & $\mathrm{~m}^{3} /$ capita/year \\
\hline & Water consumption per capita & 32 & $\mathrm{~m}^{3} /$ capita/year \\
\hline
\end{tabular}

The initial values in Table 1 are obtained from Bekasi Central Bureau of Statistics, the results of questionnaire analysis, and secondary data from Yayasan Eka Mitra as the manager of the PAP in Situ Binong. Table 2 shows the variables in socioeconomic sub-systems and natural water flows. 
Table 2. The Key's Variable for Model Sub-System.

\begin{tabular}{ll}
\hline \multicolumn{1}{c}{ Sub-System } & Feedback water from irrigation \\
\hline Pertanian & Irrigation \\
& Irrigation of ganden dan hydroponic \\
& Irrigation of paddy's field \\
& Water consumption per unit irrigation area \\
\hline Aliran air alami & Infiltration \\
& Infiltration area \\
& Initial surface runoff area \\
& Precipitation \\
& Surface area \\
& Surface run-off \\
& Birth \\
& Death \\
Populasi penduduk & Domestic waste water \\
& Domestic water consumption \\
& Ruralization \\
& Urbanization \\
Waste water \\
Wasted water consumption \\
Evaporation of WTP \\
Number of costumer \\
Number of washing vehicles \\
Tourist visit \\
Vehicles washing services \\
WTP's costumer \\
Custumer water demand \\
\hline Water Treatment Plant &
\end{tabular}

\section{The Basic Equation in The Model}

Each sub-system has a mathematical equation that represents the interaction between variables. Situ Binong water resources are influenced by the value of water supply and demand, so that the equation is represented by Equation 1.

Total water resources of Situ Binong= ACTIVE INITIAL ((Domestic waste water - Evaporation + Infiltration - Irrigation + Precipitation + "Surface run-

off" + Waste water - Water treatment plant + Feedback water from irrigation),

$$
\text { 510000) }
$$

Equation 1 shows that water resources are directly affected by demand by irrigation, WTP intake, and evaporation. While availability is influenced by the input of domestic waste, infiltration, precipitation, surface flow, and wastewater from ecotourism activities. The value of 510,000 is the initial value of Situ Binong volume in m3. This value is obtained from secondary data of PJT II. The amount of domestic waste is affected by the socioeconomic sub-system of population and ecotourism activities. The population is affected by mortality 
and birth rates, urbanization numbers, and ruralization figures. The equation for the population sub-system is shown by Equation 2.

Total Hegarmukti population= INTEG (Birth-Death-Urbanization + Ruralization, 13127)

Equation 2 shows that the population is a function of numerical integral. This means that the value of the population affected by the time of last year's population affect the population of the current year. Another equation similar to Equation 2 is the water treatment plant variable shown in Equation 3.

Water treatment plant $=$ ACTIVE INITIAL $($ Costumers water demand + Ecotourism water consumption + Evaporation of WTP + Vehicles washing services, 35478)

The evaporative sub-system is influenced by the surface area of Situ Binong. Based on the results of Google Earth imagery analysis, the surface area of Situ Binong is depreciated and added periodically every year. So for the evaporation equation shown by Equation 4 .

Evaporation $=$ INTEG (Evaporation rate*Surface area, 222888)

Surface area $=$ ACTIVE INITIAL $((74296.1)+(7680.56 *$ SIN

(Precipitation rate area + Time) $), 74296.1)$
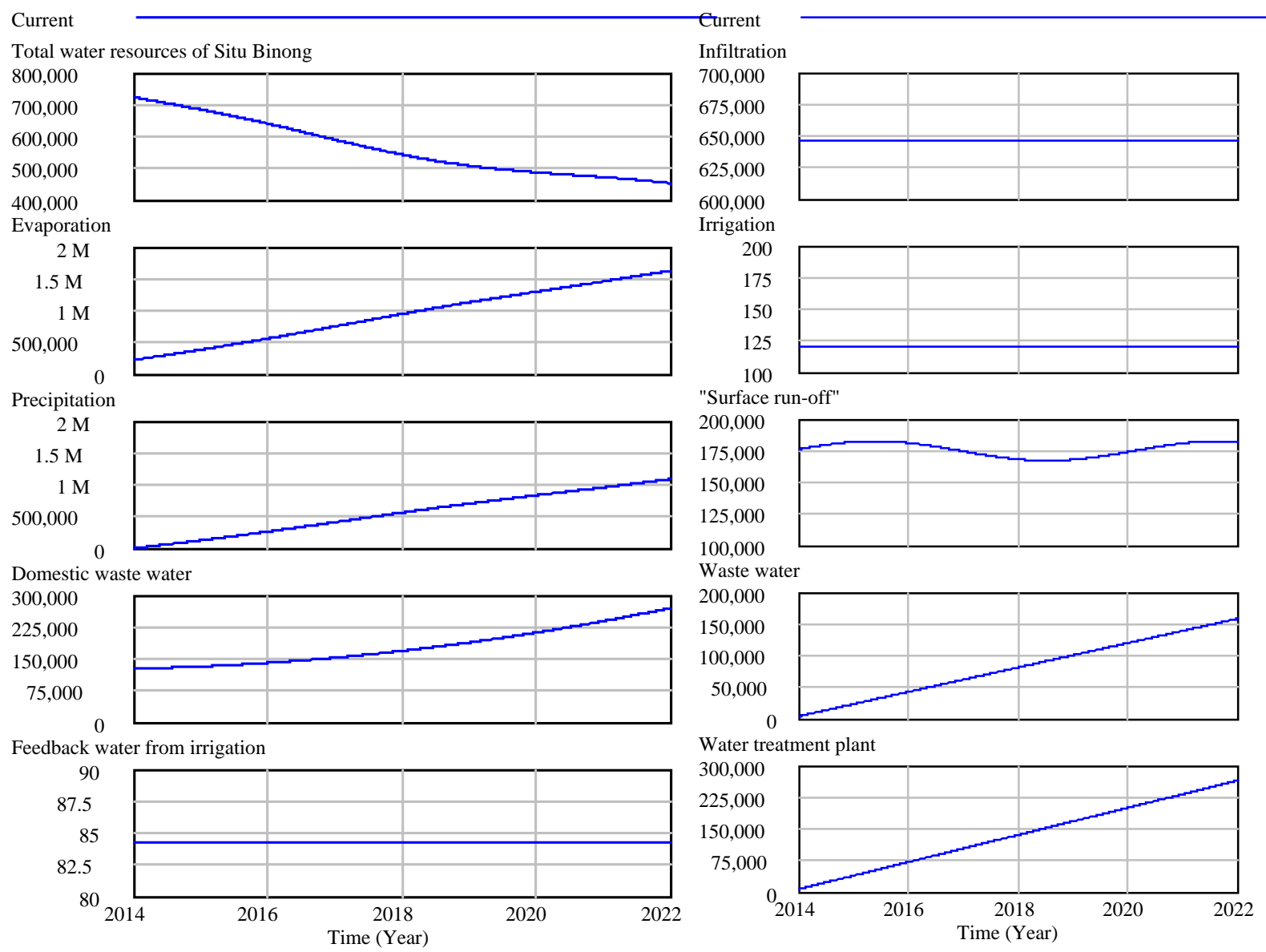

Fig. 3. Simulation Prediction of System Dynamic Model in Situ Binong. 


\section{Simulation Results and Model Predictions}

Model simulation and prediction is done up to 2022. Based on preliminary data and model equations, after the simulation program run is shown in Figure 3. Based on the model simulation results (Figure 3), the volume of Situ Binong water is reduced annually. This indicates that the water resources of Situ Binong continue to be used regardless of the sustainability of the availability of water resources.

\section{CONCLUSIONS}

Based on the results of simulation, it can be concluded that Situ Binong's water resources needs are increasing every year. This condition is caused because Situ Binong is the main water source for the people in Hegarmukti Village. Sources of clean water from local governments (regional water utilities) have not been able to reach this region. Furthermore, the volume of water resources Situ Binong is influenced by supply and demand. Supply comes from domestic waste and natural water flow such as precipitation, infiltration and surface flow. While demand comes from WTP intake, irrigation, and evaporation.

\section{ACKNOWLEDGMENT}

The research was funded by Directorate of Research and Community Service, Directorate General of Research and Development Reinforcement, Ministry of Research, Technology and Higher Education of Indonesia, Pursuant to Research Contract Number: 1598 / K4 / KM / 2017.

\section{REFERENCES}

Ercan, Tolga, Nuri Cihat Onat, and Omer Tatari. 2016. "Investigating Carbon Footprint Reduction Potential of Public Transportation in United States: A System Dynamics Approach." Journal of Cleaner Production 133:1260-76. Retrieved (http://dx.doi.org/10.1016/j.jclepro.2016.06.051).

Ford, Andrew. 1999. Modeling the Environment. An Introduction to System Dynamics Modeling of Environmental Systems. Washington: Island Press.

Kong, Rui, Fangfang Xue, Jing Wang, Haiyan Zhai, and Lina Zhao. 2017. "Research on Mineral Resources and Environment of Salt Lakes in Qinghai Province Based on System Dynamics Theory." Resources Policy 52(January):19-28. Retrieved (http://dx.doi.org/10.1016/j.resourpol.2017.01.006).

Kotir, Julius H., Carl Smith, Greg Brown, Nadine Marshall, and Ron Johnstone. 2016. "A System Dynamics Simulation Model for Sustainable Water Resources Management and Agricultural Development in the Volta River Basin, Ghana." Science of the Total Environment 573:444-57. Retrieved (http://dx.doi.org/10.1016/j.scitotenv.2016.08.081).

Liu, Hui, Gaboury Benoit, Tao Liu, Yong Liu, and Huaicheng Guo. 2015. "An Integrated System Dynamics Model Developed for Managing Lake Water Quality at the Watershed Scale." Journal of Environmental Management 155:11-23. Retrieved (http://dx.doi.org/10.1016/j.jenvman.2015.02.046).

Liu, Xue, Shoufeng Ma, Junfang Tian, Ning Jia, and Geng Li. 2015. "A System Dynamics Approach to Scenario Analysis for Urban Passenger Transport Energy Consumption and CO2 Emissions: A 
Muchammad Chusnan Aprianto/Jurnal Ilmu Alam dan Lingkungan 9 (18) (2018) 41 - 49

Case Study of Beijing." Energy Policy 85:253-70. Retrieved

(http://www.sciencedirect.com/science/

article/pii/S0301421515002256).

Shahgholian, Keyvan and Hamid Hajihosseini. 2009. "A Dynamic Model of Air Pollution , Health , and Population Growth Using System Dynamics: A Study on Tehran-Iran (With Computer Simulation by the Software Vensim)." 3(11):213-20.

Sun, Yuhuan, Ningning Liu, Jixia Shang, and Jingyu Zhang. 2017. "Sustainable Utilization of Water Resources in China: A System Dynamics Model.” Journal of Cleaner Production 142:613-25. Retrieved (http://dx.doi.org/10.1016/j.jclepro.2016.07.110).

Vafa-Arani, Hamed, Salman Jahani, Hossein Dashti, Jafar Heydari, and Saeed Moazen. 2014. "A System Dynamics Modeling for Urban Air Pollution: A Case Study of Tehran, Iran." Transportation Research Part D: Transport and Environment 31:21-36. Retrieved (http://dx.doi.org/10.1016/j.trd.2014.05.016).

Zhu, Jie, Xuan Wang, Lixiao Zhang, Hongguang Cheng, and Zhifeng Yang. 2015. "System Dynamics Modeling of the Influence of the TN/TP Concentrations in Socioeconomic Water on NDVI in Shallow Lakes." Ecological Engineering 76:27-35. Retrieved (http://dx.doi.org/10.1016/j.ecoleng.2014.06.030). 